\title{
HYPERSEASONAL CERRADO, A NEW BRAZILIAN VEGETATION FORM
}

\author{
BATALHA, M. A. ${ }^{1}$, CIANCIARUSO, M. V. ${ }^{1}$, SILVA, I. A. ${ }^{1}$ and DELITTI, W. B. C. ${ }^{2}$ \\ ${ }^{1}$ Department of Botany, Federal University of São Carlos, 13565-905, São Carlos, SP, Brazil \\ ${ }^{2}$ Department of Ecology, University of São Paulo, 05508-900, São Paulo, SP, Brazil \\ Correspondence to: Marco Antônio Batalha, Departamento de Botânica, Universidade Federal de São Carlos, \\ C. P. 676, CEP 13565-905, São Carlos, SP, Brazil, e-mail: marcobat@uol.com.br \\ Received December 9, 2003 - Accepted February 17, 2004 - Distributed November 30, 2005
}

(With 2 figures)

Savannas are tropical and subtropical formations where the grass stratum is important and continuous, occasionally interrupted by trees and shrubs, fire is frequent, and the main growth patterns are closely associated with alternating wet and dry seasons (Bourlière \& Hadley, 1983). Savanna formations constitute a substantial part of the vegetal cover of tropical America (Sarmiento, 1983). In the Neotropics, the total area occupied by savannas exceeds 2 million $\mathrm{km}^{2}$, $90 \%$ of which is occupied by the Brazilian cerrado (Sarmiento, 1983).

Seasonality is one of the most essential features that define a savanna, be it from the standpoint of the cyclic changes occurring in the environment during the year or the biological rhythms of plant species that accompany those external fluctuations (Sarmiento, 1983). Sarmiento (1984) proposed an ecological classification of savannas, whereby they are divided into four major classes according to seasonality: a) semiseasonal savannas, which occur mostly in wet climates with one or two short dry seasons; b) seasonal savannas, characterized by a season with sufficient moisture in the upper soil layers - but without waterlogging - alternating with another season with a marked soil water deficit; c) hyperseasonal savannas, with two contrasting stresses, one induced by drought and fire and the other by waterlogging; and d) marshy savannas, in which the period of excess water lasts throughout the year.

Hyperseasonal savannas occur on poorly drained bottomlands or depressed regions with slow and ill-defined drainage, especially in the Bolivian and Venezuelan llanos (Sarmiento, 1983). Hyperseasonal savannas are very restricted in the cerrado region, which is basically seasonal (Sarmiento, 1983). Moreover, what Sarmiento
(1983) considers a hyperseasonal savanna in the cerrado region, "a narrow belt separating the upland cerrado from the gallery forest", is, in fact, floodplain grassland, whose flora is completely different from the cerrado flora. Castro et al. (1998) considered some northeastern cerrado areas hyperseasonal due to the large water table fluctuations, but because of the absence of waterlogging in the wet season, those areas cannot be classified as hyperseasonal cerrados.

Emas National Park (ENP) is located in the Brazilian Central Plateau $\left(17^{\circ} 49^{\prime}-18^{\circ} 28^{\prime} \mathrm{S}\right.$; $52^{\circ} 39^{\prime}-53^{\circ} 10^{\prime} \mathrm{W}$ ) and is one of the largest and most important reserves in the cerrado region, with about 133,000 ha. Recently, ENP was included by UNESCO (2001) in the World Natural Heritage List as one of the sites containing fauna, flora, and key habitats that characterize the cerrado. The regional climate is humid tropical with wet summers and dry winters. The annual rainfall varies from 1200 to $2000 \mathrm{~mm}$, concentrated from October to March, and the mean annual temperature is around $24{ }^{\circ} \mathrm{C}$ (Ramos-Neto \& Pivello, 2000).

During a floristic survey carried out in Emas National Park (ENP) (Batalha \& Martins, 2002), we found a hyperseasonal cerrado area, which represents a new vegetation form for the Brazilian cerrado. This hyperseasonal cerrado area covers 300 ha in the southwestern portion of ENP (Fig. 1). At the end of the rainy season (from February to April), this area is waterlogged (Fig. 2), whereas, in the dry season (from June to August), there is a water shortage in the upper soil layers. The water table rises up to $0.2 \mathrm{~m}$ above soil level in the waterlogging period.

In February 2003, we carried out a survey in the hyperseasonal cerrado (approximately $18^{\circ} 18^{\prime}$ $07^{\prime \prime} \mathrm{S}, 52^{\circ} 57^{\prime} 56^{\prime \prime} \mathrm{W}$ ), which enabled us to assess 


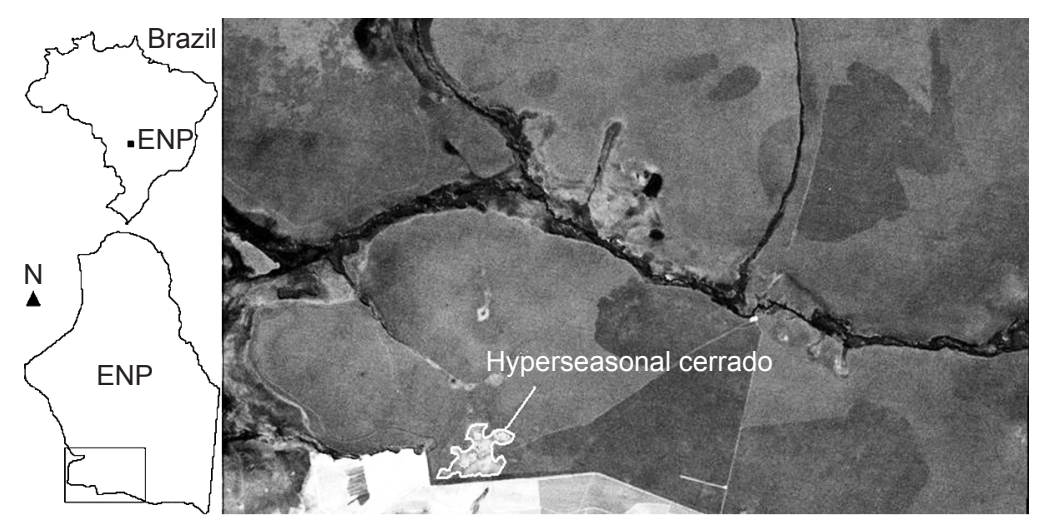

Fig. 1 - Southwestern portion of Emas National Park (18 $\left.09^{\prime}-18^{\circ} 20^{\prime} \mathrm{S}, 52^{\circ} 49^{\prime}-52^{\circ} 75^{\prime} \mathrm{W}\right)$, central Brazil, showing the hyperseasonal cerrado area.

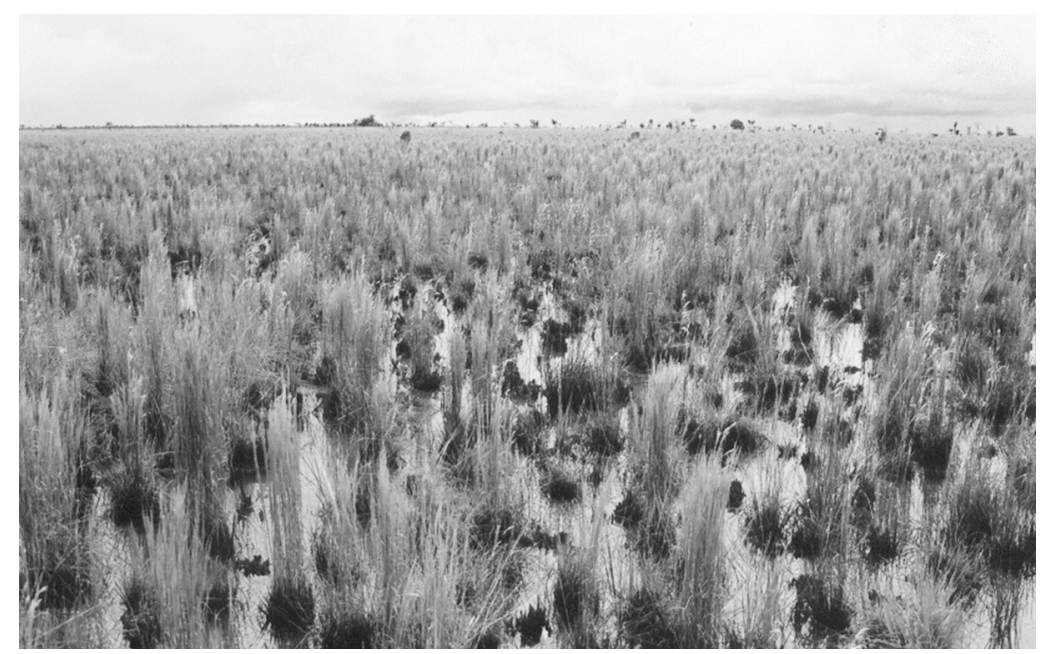

Fig. 2 - Hyperseasonal cerrado in Emas National Park (18 $18^{\prime} 07^{\prime}$ S, 52 57' 56” W), central Brazil, in February 2003, showing waterlogging.

the size and floristic composition of this vegetation form. We compared the hyperseasonal cerrado with nearby and physiognomically similar areas of seasonal cerrado (approximately $18^{\circ} 17^{\prime} 34^{\prime \prime} \mathrm{S}, 52^{\circ}$ $58^{\prime} 12^{\prime \prime} \mathrm{W}$ ), without waterlogging in the wet season, and floodplain grassland (approximately $18^{\circ} 15^{\prime}$ $40^{\prime \prime} \mathrm{S}, 53^{\circ} 01^{\prime} 08^{\prime \prime} \mathrm{W}$ ), waterlogged throughout the year. In each area, we randomly placed ten $1 \mathrm{~m}^{2}$ quadrats and counted the number of individuals of each vascular plant species. We lodged the collected material at the Federal University of São Carlos herbarium.
We calculated the similarity among the hyperseasonal cerrado, seasonal cerrado, and floodplain grassland using the Sørensen index (Magurran, 1996). For each vegetation form, we calculated richness, defined as the number of species per square meter, and tested for differences among the three vegetation forms with an analysis of variance and Tukey multiple comparison test (Zar, 1999). We calculated the power of this analysis to estimate the probability of commiting type II error (Zar, 1999). We also calculated diversity with the Shannon index (Magurran, 1996) and applied 
Hutchinson's test (Zar, 1999) to all possible pairs to test for differences among the three vegetation forms.

We sampled 18 species in the hyperseasonal cerrado, 54 species in the seasonal cerrado, and 34 species in the floodplain grassland. The similarity values were 0.28 between the hyperseasonal and seasonal cerrados, 0.04 between the hyperseasonal cerrado and the floodplain grassland, and zero between the seasonal cerrado and the floodplain grassland. Richness was significantly different among the three vegetation forms $(F=42.04$, $\mathrm{P}<0.001$ ), higher in the floodplain grassland (mean $16.80 \pm 3.29 \mathrm{SD}$ ), intermediate in the seasonal cerrado (mean $13.70 \pm 2.75 \mathrm{SD}$ ), and lower in the hyperseasonal cerrado (mean $5.09 \pm 2.02 \mathrm{SD}$ ). The ten quadrats we placed on each vegetation form sufficed to give us a power of $100 \%(\phi=5.40)$. The diversity values in the hyperseasonal cerrado, seasonal cerrado, and floodplain grassland were, respectively, $1.92,3.16$, and 2.18 nats ind $^{-1}$, all significantly different when compared in pairs $(\mathrm{P}<0.001)$.

Floristically, the hyperseasonal savanna found in ENP is a new cerrado form, since it presents typical cerrado species that Batalha \& Martins (2002) found in the seasonal cerrado and only one species found in nearby floodplain grasslands. The most abundant species is the grass Andropogon leucostachyus Kunth. Two cryptophytic palms are very common, Allagoptera campestris (Mart.) Kuntze and Syagrus flexuosa Mart. Some species, such as Acosmium dasycarpum (Vogel) Yakovlev, which can grow into tall trees in seasonal cerrado areas, are found in a dwarfish form in the hyperseasonal cerrado.

The waterlogging results from soil saturation duetorainfall, generally associated withimpermeable and poorly structured clay horizons (Sarmiento \& Monasterio, 1975). These soils are unfavorable for plant growth, remaining anaerobic during the wet season and then drying quickly soon after the rains end (Sarmiento \& Monasterio, 1975).

Physionomically, the hyperseasonal cerrado in ENP is a savanna grassland with few scattered shrubs and no trees. In hyperseasonal savannas, woody species cannot successfully compete with herbs since, with the possible exception of some palms, most trees are unable to survive alternating periods of soil-water saturation and soil drought
(Sarmiento \& Monasterio, 1975). In ENP, the herb layer of the hyperseasonal cerrado is open and the ground cover is lower than in the seasonal cerrado. In a Venezuelan hyperseasonal savanna, Monasterio \& Sarmiento (1971) also found an open herb layer even in the period of maximal development, with a ground cover of around 50 percent.

Even if the similarity between the hyperseasonal and seasonal cerrados is low, the hyperseasonal cerrado is floristically much closer to the seasonal cerrado than to the floodplain grassland. The greater similarity between the two cerrado forms and the lower richness and diversity we found in the hyperseasonal cerrado suggest that this vegetation form is an impoverished form of the seasonal cerrado. Probably the two contrasting stresses in the hyperseasonal cerrado limit the number of species able to grow in these conditions, reflecting the physiological inability of most cerrado species to tolerate waterlogging.

Acknowledgements - We are grateful to FAPESP (Brazil), for its financial support of this study; to IBAMA, for granting the research permit; to Carlos Aparecido Casali, Priscilla Kobayashi Amorim, and Renata Alonso Miotto, for their help in the field work; and to F. Nietzsche, for philosophical inspiration.

\section{REFERENCES}

BATALHA, M. A. \& MARTINS, F. R., 2002, The vascular flora of the cerrado in Emas National Park (Goiás, Central Brazil). Sida, 20: 295-311.

BOURLIÈRE, F. \& HADLEY, M., 1983, Present-day savannas: an overview, pp. 1-17. In: D. W. Goodall (ed.), Ecosystems of the world - tropical savannas, 730 p., Elsevier, Amsterdam.

CASTRO, A. A. J. F., MARTINS, F. R. \& FERNANDES, G., 1998 , The woody flora of cerrado vegetation in the State of Piauí, northeastern Brazil. Edinb. J. Bot., 55: 455-472.

MAGURRAN, A. E., 1996, Ecological diversity and its measurement. Princeton University, Princeton, 179 p.

MONASTERIO, M. \& SARMIENTO, G., 1971, Ecologia de las sabanas de América tropical I. Análisis macroecológico de los llanos de Calabozo, Venezuela. Cuad. Geogr., 4: $1-126$.

RAMOS-NETO, M. B. \& PIVELLO, V. R., 2000, Lightning fires in a Brazilian savanna National Park: rethinking management strategies. Environ. Manag., 26: 675-684.

SARMIENTO, G., 1983, The savannas of tropical America, pp. 245-288. In: D. W. Goodall (ed.), Ecosystems of the world - tropical savannas, 730 p., Elsevier, Amsterdam.

SARMIENTO, G., 1984, The ecology of neotropical savannas. Harvard University, Cambridge, $235 \mathrm{p}$.

SARMIENTO, G. \& MONASTERIO, M., 1975, A critical consideration of the environmental conditions associated 
with the occurrence of savanna ecosystems in tropical America, pp. 223-250. In: F. B. Golley \& E. Medina (eds.), Tropical ecological systems, 398 p., Springer, New York.

UNESCO. United Nations Educational, Scientific, and Cultural Organization, 2001, Cerrado protected areas: Chapada dos
Veadeiros and Emas National Parks. Unesco, Paris. http:// www.unesco.org/whc/sites/ 1035.htm.

ZAR, J. H., 1999, Biostatiscal analysis. Prentice Hall, Upper Saddle River, 663 p. 